November, Dr. Kimmins lectured at the Silviculture Institute of $\mathrm{BC}$ on predicting long term sustainability of ecosystem function and yield. At the end of November, he presented an invited paper at the Conservation of Northern Forests Symposium at the University of Toronto.

Dr. Gene Namkoong spoke at the European Forest Genetic Conservation Meeting. This meeting is related to the Canadian efforts on Boreal Forest Genetic Conservation Meeting which was held in Toronto this past summer, all of which is related to the International Conference and Process on Plant Genetic Resources.

\section{Wood Science Department}

In September, Dr. Linda Abraham successfully completed her Ph.D. in the Forest Products Biotechnology Program. Linda's research was on "Functions of a proteinase secreted by the sapstaining fungus Ophiostoma piceae." Comments from the examination panel were very positive: "The oral and written presentations reflect a student of high calibre". This is a significant graduation because Linda is the first Ph.D. graduate in the Forest Products Biotechnology program which began operations in 1990 .

Mr. Andrew Rozsa from CSIRO Division of Forest Products, Australia spent a month with Dr. Stavros Avramidis carrying out exploratory research in the area of radio-frequency/vacuum drying of eucalyptus lumber.

Drs. J.D. Barrett, Frank Lam and Helmut Prion attended the 39th annual meeting of the Canadian Standards Association Technical Committee on Engineering Design in Wood in Toronto. The group participated in the development of background information in support of changes to the timber design code aiming to improve the reliability and efficiency of timber structures. The group's activities included: (1) Development of model procedures relating specified strengths to characteristic structural properties; (2) Effect of double incising on bending strength of lumber (F. Lam and P. Morris); (3) Shear strength of Canadian softwood structural lumber (F. Lam, H. Yec and J. D. Barrett) and, (4) Top truss chord members design proposal (W. Lau, J. D. Bar).

Susan B. Watts, Ph.D., R.P.F.

\title{
STUDENT DIRECTORY
}

MCPHERSON, Scott. Box 281, 21 Classic Ave., Toronto, ON M5S 2Z3. Tel: (416) 598-3593 (until May 1996).

Graduating May 1996, B.Sc.F. University of Toronto. Ambitious and motivated. Solid computer, organization and leadership skills. Experience: pest monitoring and management, site prep. and conifer release trials, tree planting. Land Class 1 \& 3 Exterminator Licences. Awards: Dean's Admission Scholarship, R.C. Hosie Award for Dendrology and Silvics. CIF member. Willing to relocate anywhere.

DILLENBECK, Darren. 666 Mitchell St., Fredericton, New Brunswick E3B 3S6. Tel: (506) 455-7820, Email: m8v@unb.ca

I am graduating in the spring of 1996 with a Bachelor of Science in Forestry from the University of New Brunswick. My experience consists of contractor inspection/supervision, tree planting, pre-commercial thinning and public relations. I work well in a team and I thrive on responsibility. Willing to relocate and begin in May 1996.

PREST, Dwayne, Sidney, PO Box 13, Mooseland, NS BOJ 2J0. Tel: (902) 772 2082. Current address: 19 Forest Hill Rd., Apt. 48, Fredericton, NB E3B 4J9. Tel: (506) 455-4834.

I am currently a third year Forest Engineering student at the University of New Brunswick and am on schedule to graduate in the spring of 1998. I have had an opportunity to gain practical experience around the forest and forest operations. I have also been exposed to forest research and silviculture with my most recent summer employment. I enjoy being around the woods either when I am working or hunting and fishing. I would like to eventually work in the Maritimes but am planning on going out west once I graduate.

FIRN, Jennifer, 89 McCaul St., Apt. 313, Toronto, ON M5T $2 \times 3$.

Hard working and enthusiastic graduating forestry student looking for an operational position in silviculture, forest planning or harvesting operations. Have acquired valuable theoretical knowledge and functional skills in the area of silviculture. Other skills include, forest mensuration, photo-interpretation, photogrammetry, GIS, statistical analysis, data collection, and experimental design. Have developed excellent leadership, and oral and written communication skills.

DANG, Zhongyu. Faculty of Forestry, Lakehead University, 955 Oliver Rd, Thunder Bay, ON. P7B 5E1. Fax: (807) 343-81 16. Tel: (807) 343-841 1 (Office), (807) 344-6108 (Home).
Interest: forest entomology or pathology. Availability: from mid-April '96. Education: May ' 94 - April ' 96, MSc in forestry entomology at Lakehead University; Nov. '86 -Aug. '87, insect rearing at German Federal Institute of Biocontrol; Sept. ' 80 - July ' 84 , BSc in forest pest control at Beijing Forestry University. Employment: 10 years in forest entomology; 2 years in forest pathology.

WONG, Anne. Box 370, 40 Willcocks St., Toronto, ON M5S 1C6. Tel: (416) 5962426 or (416) $490-8571$ (after 3 May 1996).

Graduating Bsc.F. University of Toronto. Work experience in Timber cruising, regeneration surveys, small mammal project, data collection, and permanent sample plot measurements. Skills include organization, oral communication, computers, mensuration, and forest ecosystem classification. Worked in industry and government and have gained invaluable experience that will benefit future employers.

EAGLES, Beth. 837 York St., Fredericton, NB E3B 3R9 Tel: (506) 454-4303, e-mail:wloa@unb.ca.

1996 University of New Brunswick Graduate. Available to work starting in May 1996. Canada Scholar with work experience in regeneration surveys, cruising, entomology, and radio telemetry. Avid interest in wildlife management, ecology and human relations. Extra Curricular involvement includes UNB Forestry Association member, CIF member, Wildlife Society member, and UNB Wildlife Society President.

BOULIANE, Simon, 3440, rue Massart, Sainte-Foy (Québec), GIW 2N4. Tél. (418) 653-8009.

Baccalauréat en foresterie, aménagement des ressources forestières. Inventaires dendrométriques en pépinière et en plantation expérimentale. Évaluation de la santé (insectes, maladies) des arbres dans un parc fédéral. Établissement et suivi de dispositifs expérimentaux en génétique (croisements dirigés) et entomologie (TBE). Analyses dendrométriques de sapins beaumiers à l'aide du logiciel Windendro.

Bachelor's degree in Forestry, forest resources management. Measurement of plants in nurseries. Statistical analysis of genetics experimentation. Evaluation of tree health (diseases, insects) in a federal park. Follow-up of experimental tests in genetics (progeny test and controlled crossing) and entomology (spruce budworm). Measurement of balsalm fir stem with Windendro software. 